\title{
Effects of seven diets on the population dynamics of laboratory cultured Tisbe holothuriae Humes (Copepoda, Harpacticoida)
}

\author{
H. Miliou \& M. Moraïtou-Apostolopoulou \\ Zoological Laboratory, University of Athens; Athens 15771, Greece
}

\begin{abstract}
The harpacticoid copepod Tisbe holothuriae was collected from Saronicos Gulf (Greece) and reared under constant laboratory conditions. In order to study the effects of food on the

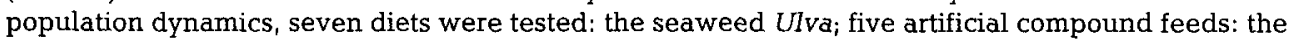
liquid Fryfood ${ }^{\circledast}$ (Waterlife), a powder of Mytilus, yeast, soya and Spirulina, respectively; and a mixed diet consisting of Ulva and Fryfood. The life cycle parameters (mortality, sex ratio, generation time, offspring production) were measured, and the demographic variables [mean generation time (T), net reproductive rate (Ro), and intrinsic rate of natural increase $\left.\left(\mathrm{r}_{\mathrm{m}}\right)\right]$ were determined. As to their efficiency regarding population dynamics, the diets ranked as follows: (1) Ulva + Fryfood, (2), Ulva, (3) Fryfood, (4) Mytilus, (5) soya, (6) yeast, and (7) Spirulina. In this order they cause a progressive increase of both larval mortality and generation time, a progressive decrease of sex ratio, number of offspring per egg sac, number of egg sacs per female and, consequently, of Ro and $r_{m}$. The observed differences between diets were most pronounced with respect to offspring production. Of the compound diets, those containing animal extracts were more efficient than those containing vegetable materials. Ulva plays an important role in the nutrition of $T$. holothuriae, favouring offspring production as well as larval survival, development and pigmentation. Ulva in combination with Fryfood led to a greater copepodid survival and offspring production. This mixed diet proved to be the most favourable for rearing the Greek population of $T$. holothuriae, resulting in an efficient intrinsic rate of natural increase $\left(r_{m}=0.304\right)$ of the population.
\end{abstract}

\section{INTRODUCTION}

Mixed diets including Artemia, rotifers, copepods and other microfauna species have been proved to give the best growth of fish larvae (Nash \& Kuo, 1975; Kuhlman et al., 1981). Of the copepods, harpacticoid copepods are the most suitable live food organisms (Rothbard, 1976; Fujita, 1977; Gopalan, 1977; Nash, 1977; Kahan, 1981).

The harpacticoid copepod Tisbe is referred to in the literature as an appropriate live prey for fish larvae in aquaculture (Uhlig, 1980; Kahan et al., 1982). In addition, Tisbe is a very suitable test organism in environmental physiology and toxicology. Furthermore, the detailed determination of the various life cycle parameters of Tisbe holothuriae living in Greek sea waters could provide useful data for taxonomists: the systematics of the genus Tisbe is complicated because of the presence of morphologically very similar species or sibling species. According to Battaglia \& Volkmann-Rocco (1973), differences in the biological cycle would support taxonomical separation.

At the Zoological Laboratory of the University of Athens we have undertaken a series 
of experiments on the importance of abiotic and biotic factors for the population dynamics of the harpacticoid copepod T. holothuriae Humes. These experiments, supported by the Greek Ministry of Agriculture, aim to study the possibility of using Tisbe living in Greek sea waters as food for fish larvae in aquaculture. This paper describes the effects of diet on the various life cycle parameters of a Greek population of $T$. holothuriae.

\section{MATERIAL AND METHODS}

Tisbe holothuriae Humes is a marine epibenthic copepod with widespread distribution in the coastal environment. The animals used in these experiments were collected from the Saronicos Gulf of Greece (Lagonissi area) and cultured under laboratory conditions. In order to allow acclimatization, work began on the second generation derived from the wild population. Preliminary experiments showed increased mortality and lower reproductive capacity of the first generation. Offspring up to the fourth generation only were used in order to avoid inbreeding effects.

All experiments were run in constant-temperature rooms at $19{ }^{\circ} \mathrm{C}( \pm 0.5)$ and $38 \% \mathrm{~S}$. These conditions were proved, in previous experiments (Miliou \& Moraitou-Apostolopoulou, in press), to be the most favourable for rearing the Greek population of $T$. holothuriae. A number of fertilized females G1 (second generation derived from the wild generation) were isolated from the mass culture (a single mating is sufficient to ensure production of several egg sacs by a female). Their offspring were observed daily until the appearance of fertilized females G2. When the G2 females were carrying their first egg $\mathrm{sac}$, they were put individually into $50-\mathrm{ml}$ bowls. Ten to twenty nine females were used for each experiment. After the appearance of a new egg sac, the females were transferred to a new bowl. The larvae from the previous egg sac were left in the original container and gave the G3.

All bowls were examined daily and the following parameters of the biological cycle were measured:

(1) Times from hatching of G2 females to the release of their sucessive broods (generation times, $\mathrm{x}$ ). The minimum generation time is the age of G2 females at the release of nauplii from the first egg sac.

(2) Number of nauplii at the time of hatching (no. of offspring per egg sac).

(3) Number of egg sacs per female.

(4) Total number of offspring per female.

(5) Mortality during development. The G3 offspring were observed daily for 12 days. Nauplii and copepodids were counted under a binocular microscope and transferred to new containers. For each trophic condition, 15 recipients were used with about 40 newly hatched nauplii each. The $\mathrm{LT}_{50}$ was calculated from the daily percentage mortality: time needed for the death of $50 \%$ of the individuals (UNEP: Reference methods for marine pollution studies, 1987).

(6) Sex ratio. The percentage of females among G3 adults.

(7) Number of G3 females derived from G2 females.

The measurement of these parameters enables the determination of the demographic variables: mean generation time $(\mathrm{T})$, net reproductive rate $(\mathrm{Ro})$, and intrinsic rate of natural increase $\left(\mathrm{r}_{\mathrm{m}}\right)$, which allow a prediction as to the capacity of $T$. holothuriae populations to proliferate under given environmental conditions. 
The mean generation time $(T)$ is defined as $T=\frac{\Sigma(x \cdot U x)}{\Sigma U x}$, where $\mathrm{x}$ is the age (in days) of females G2 at the time of hatching of nauplii and $U x$ is the number of nauplii per egg sac. The net reproductive rate $\mathrm{Ro}=\frac{\mathrm{G} 3}{\mathrm{G} 2}$ indicates the replacement rate of ovigerous females G2 by their female progeny G3 from one generation to another. The intrinsic rate of natural increase $\left(r_{m}\right)$ results from the relation $r_{m}=\frac{\ln R o}{T}$.

General methods for the calculation of the demographic variables are given by Andrewartha \& Birch (1954). The method applied to Tisbe population in this work is that of Gaudy \& Guérin (1977).

Seven different diets were tested: (1) Ulva + Fryfood; (2) Ulva; (3) Fryfood; (4) Mytilus; (5) soya; (6) yeast; and (7) Spirulina.

U lv a was collected from the same biotope in which Tisbe was found. The fronds of Ulva, cleaned of microorganisms and cysts under a binocular microscope, were cut into small pieces.

Mytilu s soft parts were dried at $60^{\circ} \mathrm{C}$ for $24 \mathrm{~h}$, finely ground and kept at $4{ }^{\circ} \mathrm{C}$.

Fryfood (Waterlife) is a liquid product of high nutritional value. It is composed of the following micronised ingredients: Artemia, Daphnia, Spirulina, Mysis, yeast, whitefish, whole egg, mosquito larvae, spinach, and is enriched with the vitamins A, B1, B2, B6, B12, C, E.

Soy a granular. It consists of $41.4 \%$ proteins, $2 \%$ phospholipids, $19 \%$ fatty acids, $25 \%$ carbohydrates, $0.2 \%$ calcium, $0.6 \%$ phosphates and a variety of enzymes.

Yeast superzym. Rich in amino-acids, metals, enzymes and a rich vitamin complex.

Spirulina ( Lanes). It is composed of the phytoplanktonic organism Spirulina. It is the richest of all tested diets in proteins $(68 \%)$, and contains 21 amino-acids including phenylalanine.

The selection of these types of food was based on the literature and their local availability. The aim of the experiments was to investigate the qualitative rather than the quantitative effects of food. Therefore, food was offered in excess, its quantity being adjusted to avoid accumulation of discarded material between feeding times.

Nauplii and older stages fed actively on food particles. Fryfood, a dense non-miscible liquid product, accumulated at the bottom of the containers. Copepods came into contact and fed directly on it. According to Gillet \& Guérin (1976) and Uhlig (1980), the food particles offered to Tisbe must not exceed $250 \mu \mathrm{m}$ in diameter. Larger particles were removed using a plankton net of an appropriate mesh size.

For the statistical evaluation, the pairs (Mann-Whitney) nonparametric test was applied as the size of the samples was smaller than 40 . Using normal approximation, we calculated the test statistic $z$. Since $z>1.96$ we reject the null hypothesis that the samples have the same median. In the results, the two tailed probability (P) of equaling or exceeding $\mathrm{z}$ is given. If $\mathrm{P} \leqslant 0.05$, the samples have a statistically significant difference (Zar, 1984).

\section{RESULTS}

Table 1 shows the daily percentage mortality of the G3 offspring for each tested diet. The mortality curves were transformed to linear lines according to the equation:

$y=a+b \ln x ; y$ : percentage mortality, $x$ : day. 
Table 1. Daily percentage mortality of Tisbe holothuriae during larval development under different food conditions

\begin{tabular}{|rrrrrrrr|}
\hline Day & $\begin{array}{c}\text { Ulva }+ \\
\text { Fryfood }\end{array}$ & Ulva & Fryfood & Mytilus & Soya & Yeast & Spirulina \\
\hline 1 & 0.00 & 0.00 & 0.00 & 0.00 & 0.00 & 0.00 & 0.00 \\
2 & 12.12 & 13.43 & 15.63 & 17.07 & 17.86 & 19.57 & 21.95 \\
3 & 19.70 & 20.14 & 23.13 & 25.61 & 26.98 & 27.83 & 36.59 \\
4 & 24.24 & 25.69 & 28.13 & 29.88 & 30.95 & 33.04 & 41.87 \\
5 & 28.41 & 30.79 & 33.75 & 35.37 & 36.90 & 39.13 & 48.78 \\
6 & 31.82 & 34.95 & 37.50 & 39.63 & 40.87 & 45.65 & 53.66 \\
7 & 34.47 & 38.66 & 41.25 & 43.60 & 47.62 & 53.91 & 62.60 \\
8 & 36.74 & 43.75 & 48.13 & 50.91 & 52.78 & 60.87 & 67.89 \\
9 & 38.64 & 49.31 & 53.13 & 57.01 & 61.11 & 67.83 & 73.17 \\
10 & 40.53 & 54.17 & 58.13 & 60.98 & 63.89 & 70.87 & 79.67 \\
11 & 42.42 & 59.72 & 63.75 & 64.94 & 69.05 & 76.09 & 82.93 \\
12 & 43.94 & 62.73 & 66.88 & 68.90 & 73.02 & 80.87 & 85.77 \\
\hline
\end{tabular}

This linear regression line proved to be the "best fit" line through the data of the percentage mortality per day. The parameters $a$ and $b$ were calculated using the criterion of the least squares. The obtained values of the constant $a$, the regression coefficient $b$ and the correlation coefficient $r$, for each type of food, are given in Table 2 .

This smoothing extrapolation technique allows the calculation of the time ( $\left.\mathrm{LT}_{50}\right)$ needed for $50 \%$ death of the initial nauplii. Figure 1a shows the calculated values of LT $_{50}$ for the seven diets. It can be seen that the mixed diet consisting of Ulva and Fryfood is the most favourable for the survival of Tisbe, while Spirulina is the least favourable.

Figure $1 \mathrm{~b}$ presents the sex ratio of Tisbe fed on the different diets. As in the case of survival, the mixture of Ulva and Fryfood proved to be the most favourable, giving the highest percentage of females, while Spirulina proved to be the least favourable.

Table 3 shows the mean values (and standard deviations) of some main life cycle parameters (generation times, no offspring of G2 females) for each type of food. Figures 1c-f give the mean values of: minimum generation time (Fig. 1c); number of the first egg sac offspring (Fig. 1d); number of egg sacs per female (Fig. 1e); total number of offspring

Table 2. Constant $a$, regression coefficient $b$, correlation coefficient $r$, and standard error of estimate (S.E.E.) of the linear regression for daily percentage mortality (Table 1) under different food conditions

\begin{tabular}{|lrccc|}
\hline Type of food & $\mathrm{a}$ & $\mathrm{b}$ & $\mathrm{r}$ & S.E.E. \\
\hline Ulva + Fryfood & 0.008 & 17.657 & 0.0098 & 0.1693 \\
Ulva & -10.914 & 27.688 & 0.9763 & 3.6953 \\
Fryfood & -9.659 & 28.799 & 0.9752 & 3.9357 \\
Mytilus & -8.051 & 29.157 & 0.9773 & 3.8004 \\
Soya & -9.327 & 31.201 & 0.9763 & 4.1575 \\
Yeast & -12.277 & 35.558 & 0.9784 & 4.5196 \\
Spirulina & -5.930 & 36.027 & 0.9908 & 2.9518 \\
\hline
\end{tabular}



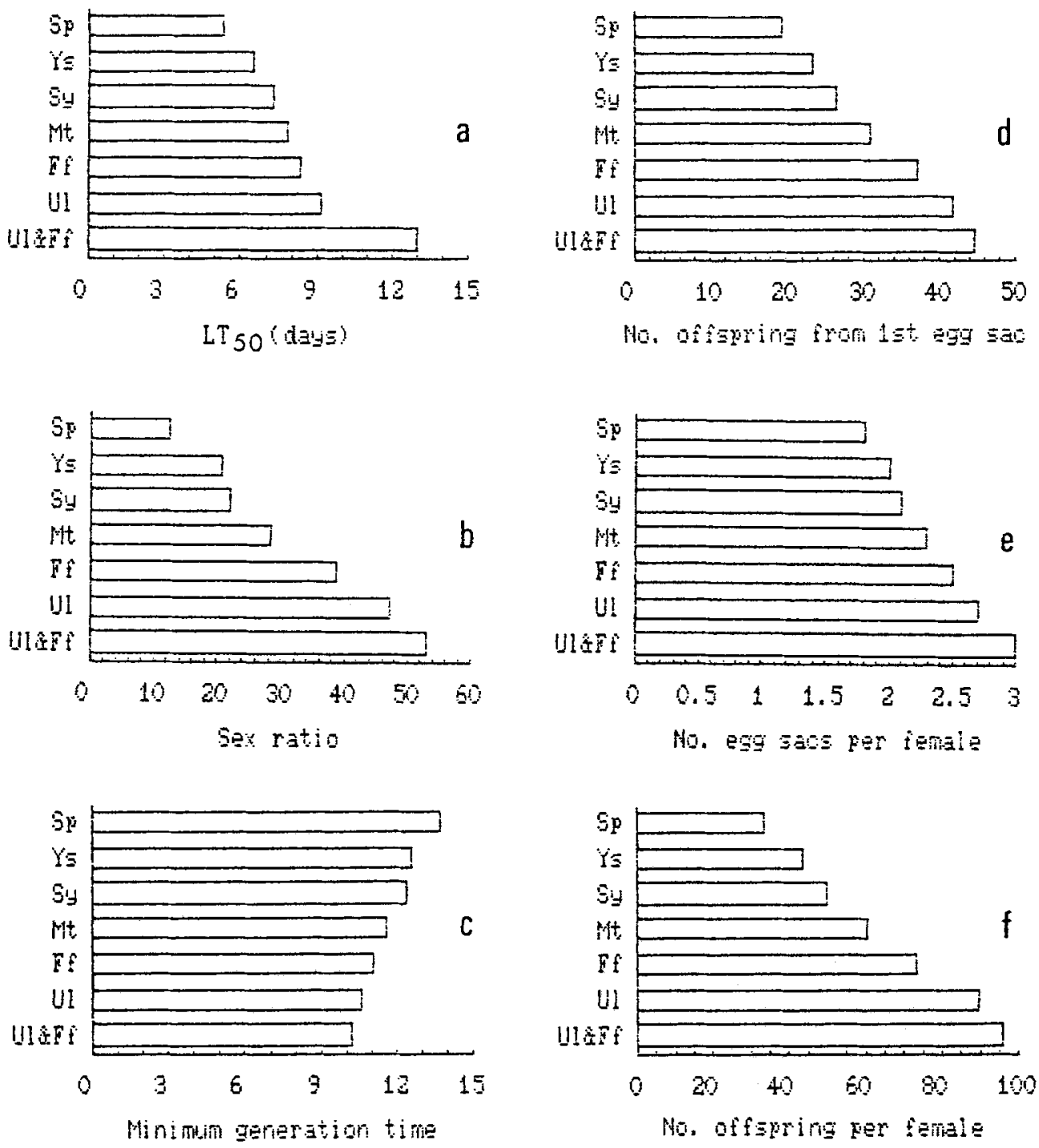

Fig. 1. Histograms illustrating the effects of seven diets on (a): $\mathrm{LT}_{50},(\mathrm{~b})$ : sex ratio (\% females among adults), (c): minimum generation time, (d): no. offspring from the first egg sac, (e): no. egg sacs per female, (f): no. offspring per female

per female (Fig. 1f). It is important to note that the first egg sac always gave a greater number of offspring than the subsequent egg sacs, under all trophic conditions. It is for this reason that parameter (d) is taken into account here.

From the above measurements we calculated the three demographic variables: $T$ (mean generation time), Ro (net reproductive rate) and $r_{m}$ (intrinsic rate of natural increase). The obtained values are illustrated in Figures $2 a, 2 b$, and $2 c$, respectively. For these calculations, only the generation times $(x)$ and the number of offspring $(U x)$ of the 
Table 3. Tisbe holothuriae: mean values \pm SD of some main life cycle parameters related to different diets

\begin{tabular}{|lcccccc|}
\hline Diet & $\begin{array}{c}\text { Generation } \\
\text { time (1st } \\
\text { egg sac) }\end{array}$ & $\begin{array}{c}\text { Generation } \\
\text { time (2nd } \\
\text { egg sac) }\end{array}$ & $\begin{array}{c}\text { No. offspring } \\
\text { from 1st } \\
\text { egg sac }\end{array}$ & $\begin{array}{c}\text { No.offspring } \\
\text { from 2nd } \\
\text { egg sac }\end{array}$ & $\begin{array}{c}\text { No.offspring } \\
\text { from 3rd } \\
\text { egg sac }\end{array}$ & $\begin{array}{c}\text { No.G3 } q \\
\text { No.G2 } q\end{array}$ \\
\hline Ulva + & & & & & & \\
$\quad$ Fryfood & $10.2 \pm 0.40$ & $12.7 \pm 0.87$ & $44.6 \pm 5.12$ & $25.7 \pm 2.68$ & $17.6 \pm 1.25$ & $468 / 16$ \\
Ulva & $10.6 \pm 0.49$ & $13.1 \pm 0.70$ & $41.6 \pm 4.53$ & $23.4 \pm 4.76$ & $15.6 \pm 4.96$ & $210 / 15$ \\
Fryfood & $11.1 \pm 0.83$ & $13.8 \pm 0.74$ & $37.1 \pm 4.74$ & $21.7 \pm 4.60$ & $14.5 \pm 1.50$ & $102 / 12$ \\
Mytilus & $11.6 \pm 1.20$ & $14.2 \pm 1.25$ & $31.0 \pm 3.83$ & $19.2 \pm 5.07$ & $10.5 \pm 1.50$ & $66 / 15$ \\
Soya & $12.4 \pm 1.28$ & $14.9 \pm 1.13$ & $26.5 \pm 4.68$ & $15.0 \pm 3.39$ & $8.5 \pm 1.50$ & $39 / 15$ \\
Yeast & $12.6 \pm 1.20$ & $15.5 \pm 1.20$ & $23.5 \pm 3.59$ & $13.3 \pm 2.87$ & $7.0 \pm 0.00$ & $21 / 15$ \\
Spirulina & $13.7 \pm 1.61$ & $15.9 \pm 1.04$ & $19.5 \pm 3.59$ & $11.0 \pm 2.00$ & $3.0 \pm 0.00$ & $6 / 12$ \\
\hline
\end{tabular}
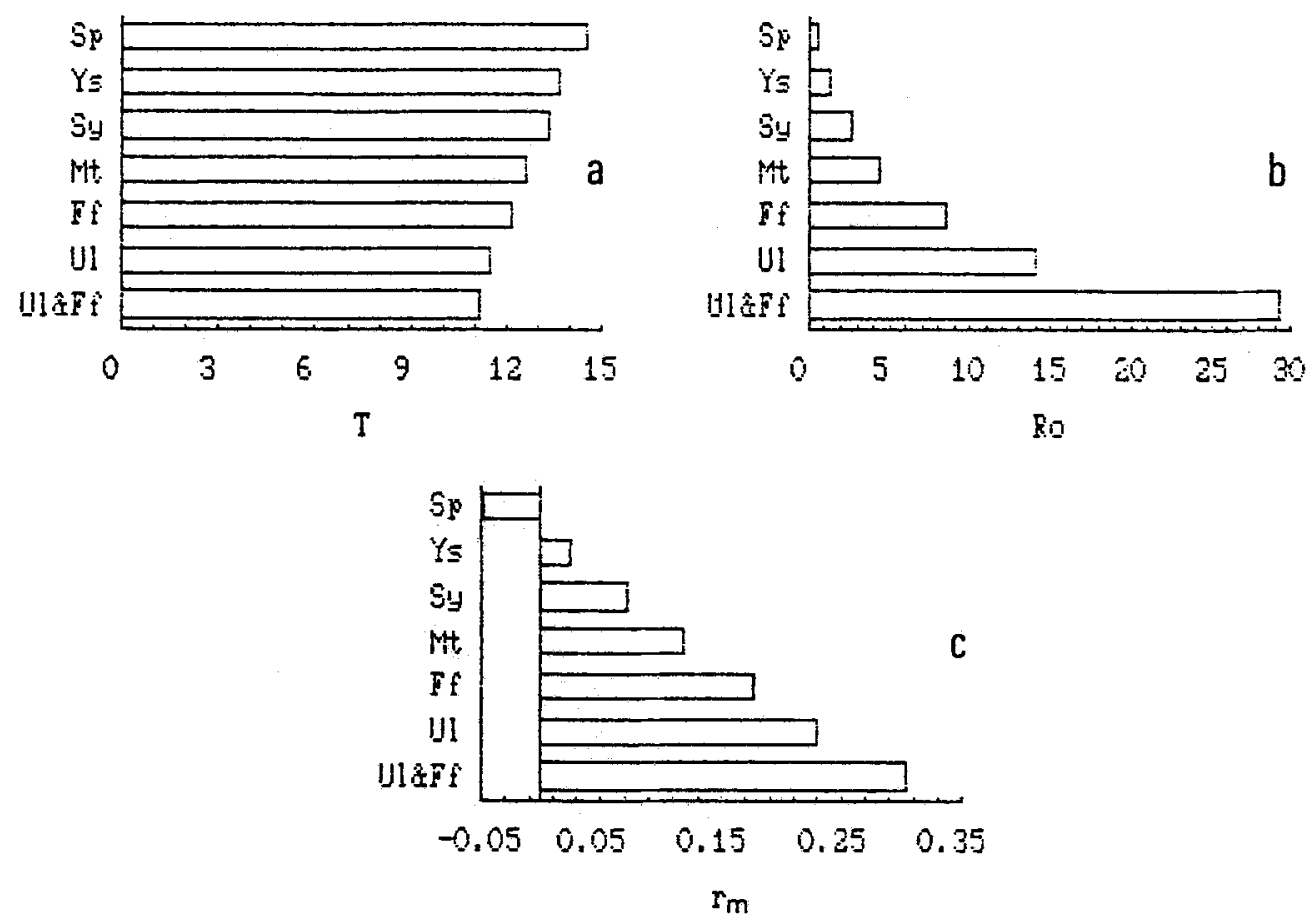

Fig. 2. Histograms illustrating the effects of seven diets on the demographic variables of the population dynamics of Tisbe holothuriae. a: mean generation time (T), b: net reproductive rate (Ro), c: intrinsic rate of natural increase $\left(r_{m}\right)$

first two egg sacs are taken into account, as these gave the majority of a female's total offspring (see Table 3).

The histograms (Figs 1 and 2) reveal the following rank of the diets as far as their efficiency regarding Tisbe productivity is concerned: (1) Ulva + Fryfood, (2) Ulva, (3) Fryfood, (4) Mytilus, (5) soya, (6) yeast, and (7) Spirulina. 
In this order, the diets cause a progressive decrease of $\mathrm{LT}_{50}$ (Fig. 1a), sex ratio (Fig. 1b), number of offspring from the first egg sac (Fig. 1d), number of egg sacs per female (Fig. 1e), total number of eggs (Fig. 1f), and Ro (net reproductive rate), which depends primarily on offspring production, survival and sex ratio (Fig. 2b).

In contrast, in the same order the diets give a progressive increase of the time needed for the appearance of the nauplii of the first egg sac (Fig. 1c), causing an increase of $T$ (Fig. 2a) which depends mainly on the time needed for development and maturation.

In the same order, the $r_{m}$-values (Fig. $2 \mathrm{c}$ ) show a progressive reduction, turning negative for Spirulina. This means that Spirulina leads to decline and finally disappearance of the initial population.

The Mann-Whitney test has been applied to each pair of values of (a) the percentage mortality in respective days, (b) the minimum generation time, and (c) the offspring production from the first egg sac. Table 4 shows the two tailed probability (P) of equaling

Table 4. Mann-Whitney nonparametric test: two tailed probability $(\mathrm{P})$ of equaling or exceeding $\mathrm{z}$. $P \leq 0.05$ : significant differences

\begin{tabular}{|c|c|c|c|c|c|c|c|}
\hline \multicolumn{8}{|c|}{ Mortality during development } \\
\hline \multicolumn{2}{|c|}{ Ulva + Fryfood } & Ulva & Fryfood & Mytilus & Soya & Yeast & Spirulina \\
\hline Ulva + Fryfood & $\star$ & & & & & & \\
\hline Ulva & 0.2643 & * & & & & & \\
\hline Fryfood & 0.1679 & 0.6936 & $\star$ & & & & \\
\hline Mytilus & 0.0878 & 0.4307 & 0.7427 & * & & & \\
\hline Soya & 0.0569 & 0.2934 & 0.5994 & 0.6458 & $*$ & & \\
\hline Yeast & 0.0302 & 0.1486 & 0.2643 & 0.3933 & 0.5545 & * & \\
\hline Spirulina & 0.0039 & 0.0356 & 0.0569 & 0.1007 & 0.1486 & 0.3933 & * \\
\hline \multicolumn{8}{|c|}{ Minimum generation time } \\
\hline \multicolumn{2}{|c|}{ Ulva + Fryfood } & Ulva & Fryfood & Mytilus & Soya & Yeast & Spirulina \\
\hline Ulva + Fryfood & $\star$ & & & & & & \\
\hline Ulva & 0.2039 & $\star$ & & & & & \\
\hline Fryfood & 0.0357 & 0.1787 & $\star$ & & & & \\
\hline Mytilus & 0.0099 & 0.0484 & 0.4298 & * & & & \\
\hline Soya & 0.0004 & 0.0012 & 0.0341 & 0.2129 & $\star$ & & \\
\hline Yeast & 0.0003 & 0.0006 & 0.0111 & 0.1033 & 0.6970 & $\star$ & \\
\hline Spirulina & 0.0001 & 0.0001 & 0.0007 & 0.0078 & 0.0807 & 0.1603 & * \\
\hline \multicolumn{8}{|c|}{ No. offspring from 1st egg sac } \\
\hline \multicolumn{2}{|c|}{ Ulva + Fryfood } & Ulva & Fryfood & Mytilus & Soya & Yeast & Spirulina \\
\hline Ulva + Fryfood & * & & & & & & \\
\hline Ulva & 0.4691 & * & & & & & \\
\hline Fryfood & 0.0093 & 0.1994 & * & & & & \\
\hline Mytilus & 0.0051 & 0.0103 & 0.0776 & * & & & \\
\hline Soya & 0.0051 & 0.0051 & 0.0202 & 0.1720 & * & & \\
\hline Yeast & 0.0051 & 0.0051 & 0.0082 & 0.0247 & 0.2963 & * & \\
\hline Spirulina & 0.0051 & 0.0051 & 0.0051 & 0.0064 & 0.0542 & 0.1269 & * \\
\hline
\end{tabular}


or exceeding $z$. The statistical treatment of the three parameters mentioned above reveals the existence of subgroups in this classification of types of food, depending on the tested parameter.

Concerning mortality, the mixed diet of Ulva + Fryfood is different from the other foods (only from yeast and Spirulina in statistically significant levels), causing an important decrease of mortality. Concerning minimum generation time, the diets Ulva + Fryfood and Ulva alone are clearly separated from the others. Ulva causes an important decrease of the time needed for development and maturation of offspring.

As to offspring production, the mixed diet Ulva + Fryfood, and Ulva and Fryfood given separately, show similar results, significantly different from the other diets. The number of offspring from the first egg sac increases with both Fryfood and Ulva, but especially when these are offered simultaneously.

With respect to all parameters considered, Spinulina was the least efficient food. Mytilus and Fryfood gave almost the same results, and this was also the case for soya and yeast.

The differences between the seven diets as to offspring production and generation time were more pronounced than those concerning mortality which were often not statistically significant.

\section{DISCUSSION}

Tisbe is known to demonstrate an opportunistic feeding behaviour, utilizing various sources of food such as bacteria, unicellular algae, detritus, vegetables (Battaglia, 1970; Gaudy \& Guérin, 1977; Rieper, 1978). However, the study of the influence of diet on the population dynamics of Tisbe has proved that food is an important factor in the regulation of the productivity of Tisbe populations. All life cycle parameters were affected to a greater or lesser degree by the type of food offered. Gaudy \& Guérin (1977), feeding Tisbe with the two diets Germalyne and Renutryl, found also significant variations in population measurements dependent on diet.

The demographic variable $r_{m}$ (intrinsic rate of natural increase) which characterizes population proliferation, was found to vary from 0.304 under the best nutritional conditions (Ulva + Fryfood) to 0.24 for yeast. For Spirulina, negative values of $r_{m}(-0.048)$ have been noted. The $r_{m}$ values obtained under optimal trophic conditions for the Greek population of Tisbe holothuriae are considered satisfactory, compared with the maximum $r_{\mathrm{m}}: 0.301$ (Aliment Bioter) and 0.313 (Renutryl), found by Gaudy \& Guérin (1977) and Gaudy et al. (1982), respectively, for the French population of Tisbe holothuriae, under the same temperature/salinity conditions.

The productivity of Tisbe populations is directly correlated with the following life cycle parameters: (a) survival during development, (b) sex ratio, (c) number of egg sacs per female, (d) number of offspring per egg sac, (e) development rate. One type of food might favourably affect one particular parameter, e.g. Ulva substantially increases the developmental rate of nauplii and copepodids, decreasing the mortality especially of nauplii. On the other hand, Fryfood, in comparison with the other compound diets, causes an important increase of offspring production and lowers the mortality especially of copepodids. Of the seven tested diets, the mixed diet of Ulva + Fryfood gives the best results. Either component has a substantially favourable effect on different parameters of the population dynamics. 
The effectiveness of a type of food depends on its digestibility and on how it fulfils the nutritional requirements of the species. The food quality has been proved to be particularly important in crustaceans especially for fertilitiy and fecundity (Provasoli et al., 1959).

The amino-acid content does not seem to be a decisive factor in the effectiveness of a food, since Spirulina, although richest in amino-acid, was the least efficient one. The amino-acid composition of copepods is of a somewhat conservative nature (Raymont et al., 1975). The fatty-acid content of food seems to influence copepod productivity, especially survival of copepodids and number of eggs.

Studies on the chemical composition of copepods have shown that their fatty acids are dominated by (n-3) polyunsaturated fatty acids (P.U.F.A.) (Sargent \& Falk-Petersen, 1981). It is noteworthy that in the presence of a substantial input of dietary fatty-acids, especially polyunsaturated ones, the de novo fatty-acid biosynthesis no longer proceeds. The conversion of dietary wax esters into fatty acids may be advantageous to the animal as this requires little or no energy expenditure (Wakil et al., 1983). Mytilus is a food rich in lipids, particularly in unsaturated fatty acids. Fryfood is also enriched with unsaturated fatty acids. In contrast, Spirulina with a low fatty acid content proved to be inefficient. Soya is more efficient than yeast, and is also richer in lipids.

In the present study, the pure animal feed (Mytilus) and animal-derived feeds (Fryfood) proved to be more efficient than the compound vegetarian feeds (soya, yeast, Spirulina). Guérin \& Gaudy (1977) suggest that Tisbe holothuriae displays a higher productivity and lipid content when fed on compound artificial diets of animal substances than when fed on diets of vegetarian origin or on living unicellular algae. Gopalan (1977) also mentioned that the cultures of the harpacticoid copepod Nitocra spinipes Boek displayed higher productivity when fed on shrimp head meal than on live Chlorella.

Diet-induced differences in enzymatic processes of copepods seem to play an important role in the effectiveness of a food. In Tisbe, varying trophic conditions are responsible for differences in the relative activity of different isoenzymes (Guérin \& Kerabrun, 1982). Hirche (1981) found that the amylase activity in adult females positively correlated with the chlorophyll a concentration of the diet. This observation can further explain the efficiency of Ulva. Furthermore, the activity of a basic digestive enzyme of zooplankton (laminarase) was found to be more intense when food is rich in laminarin, a substance abundant in marine plants (Hasset \& Landry, 1982).

In our experiments, a total loss of pigmentation was observed when Tisbe was fed on any one food exclusively, with the exception, however, of Ulva. Tanaka et al. (1976) reported that the total carotenoid content in crustaceans varies according to food type.

Mixed diets seem to fulfil the nutritional requirements for high Tisbe productivity better than other diets, probably due to a richer supply of trace elements and vitamins. Fryfood, which proved to be a very efficient feed $\left(r_{m}=0.177\right)$, contains a variety of items (plants and animals). Furthermore, Fryfood is enriched with vitamins and trace metals. Its combination with the live alga Ulva can also be considered a highly suitable diet for Tisbe. Takano (1971) reported that when a combination of live algae with non-living materials was fed to Tigriopus japonicus, the population density of the latter increased faster for 2 to 6 days than was the case using separated foods.

The favourable influence of a type of food may not be directly related to its chemical composition. For example, the fronds of Ulva significantly increase the substratum 
available to Tisbe. Gaudy \& Guérin (1979) report that the increase in the surface-volume ratio in breeding tanks results in an increase in Tisbe production. Moreover, in the presence of a live seaweed, oxygen is supplied and toxic compounds of nitrogen and other elements are absorbed through the process of photosynthesis (Harlin, 1978). Finally, the efficiency of the fronds as shelter should not be overlooked (Itami \& Yoshinori, 1977).

Fryfood, apart from the variety of food items, offers a large particle spectrum that corresponds to the changing size of the Tisbe oral parts in the course of development. The substantial decrease in copepodid mortality and the increase in offspring production when Tisbe is fed on Fryfood must be attributed to this fact as well. Nassogne (1970) reports that Euterpina acutifrons has a higher growth rate and reproductive capacity when fed on a mixture of materials of different sizes, as nauplii cannot eat particles larger than $16 \mu \mathrm{m}$, and adults cannot ingest particles smaller than $7 \mu \mathrm{m}$.

Seaweeds (Rothbard, 1976) and vegetables (Kahan, 1979) become available as food to nauplii and copepodids when the latter perforate the small cells of the epidermal cuticle of these plants. This fact could contribute to the low mortality of the nauplii of Tisbe fed on Ulva.

Finally, the success of a diet is also related to its capability of offering an appropriate substratum for bacteria to proliferate (Coull, 1973; Rieper, 1978). In benthic harpacticoid copepods, the rate of bacteria assimilation is 8 to 10 times higher than in phytoplankton (Brown \& Sibert, 1977). In addition, bacteria serve as food to microzooplankton (mainly ciliates) on which the harpacticoid copepods feed (Rieper \& Flotow, 1981). Ulva becomes a food source both directly and indirectly, acting as substratum for adhesive diatoms, bacteria and organic particle accumulation (Rothbard, 1976).

The mixture Ulva + Fryfood offers all these advantages and proved to be the most satisfactory diet for Tisbe production $\left(\mathrm{r}_{\mathrm{m}}=0.304\right)$.

Gaudy \& Guérin (1979) suggested that a perfect diet, besides its being suitable for optimum production, should be cheap and simple. The liquid Fryfood offers simplicity in the maintenance of the cultures as it represents an easily available, qualitatively adapted food supply. The extensive natural quantities of Ulva provide a low-cost and very accessible supply of this food resource. The mixed diet of Ulva and Fryfood fulfils all the above mentioned criteria, and so we suggest that it is suitable for mass production of Tisbe.

Acknowledgements. We wish to thank Dr. G. Verriopoulos for continuous support throughout this study and his valuable advice. This research was financially supported by the Greek Ministry of Agriculture (Department of Fisheries and Aquaculture).

\section{LITERATURE CITED}

Andrewartha, H. G. \& Birch, L. C., 1954. The distribution and abundance of animals. Univ. of Chicago Press, Chicago, 782 pp.

Battaglia, B., 1970. Cultivation of marine copepods for genetic and evolutionary research. Helgoländer wiss. Meeresunters. 20, 385-392.

Battaglia, B. \& Volkmann-Rocco, B., 1973. Geographic and reproductive isolation in the marine harpacticoid copepod Tisbe. - Mar. Biol. 19, 156-160. 
Brown, T. J. \& Sibert, J. R., 1977. Food of some benthic harpacticoid copepods. - J. Fish. Res. Bd Can. 34, 1029-1031.

Coull, B. C., 1973. Estuarine meiofauna: a review. Trophic relationships and microbial interactions. In: Estuarine microbial ecology. Ed. by L. H. Stevenson \& R. R. Colwell. Univ. South Carolina Press, Columbia, 499-512.

Fujita, S., 1977. The present status and problems of marine fish breeding techniques in Japan. Proc. Japan-Soviet Joint Symp. Aquacult. 5, 327-338.

Gaudy, R. \& Guérin, J. P., 1977. Dynamique des populations de Tisbe holothuriae Humes 1957, en élevage sur trois régimes artificiels différents. - Mar. Biol. 39, 137-145.

Gaudy, R. \& Guérin, J. P., 1979. Rearing of harpacticoid copepods (Tisbe holothuriae) for a complete cycle. Role played by temperature and nutrition. In: Colloque national "Eloctron". Mécanismes et contrôle de la production biologique marine. Systèmes clos artificiels, écosystèmes littoraux. CNEXO, Paris, 377-390.

Gaudy, R., Guérin, J. P. \& Moraïtou-Apostolopoulou, M., 1982. Effect of temperature and salinity on the population dynamics of Tisbe holothuriae Humes (Copepoda, Harpacticoida) fed on two different diets. - J. exp. mar. Biol. Ecol. 57, 257-271.

Gillet, D. \& Guérin, J. P., 1976. Étude de la production de Tisbe holothuriae Humes dans diverses conditions d'élevage. In: Proceedings of the 10th European Symposium on Marine Biology. Ed. by G. Persoone \& E. Jaspers. Universa Press, Wetteren, 1, 161-170.

Gopalan, U. K, 1977. Experimental mass culture of a harpacticoid copepod Nitocra spinipes Boek. In: Proceedings of the Symposium on Warm Water Zooplankton. National Institute of Oceanography, Goa, 558-562.

Guérin, J. P. \& Gaudy, R., 1977. Étude des variations du poinds sec et de la constitution chimique élémentaire de Tisbe holothuriae (Copepoda, Harpacticoida) élevé sur différents régimes artificiels. - Mar. Biol. 44, 65-70.

Guérin, J. P. \& Kerabrun, P., 1982. Effects of diet on esterases, alkaline phosphatase, malate dehydrogenase and phosphoglucomutase activity observed by polyacrylamide gel electrophoresis in Tisbe holothuriae (Harpacticoid Copepod). - Comp. Biochem. Physiol. 73B, 761-770.

Harlin, M. M., 1978. Nitrate uptake by Enteromorpha sp. (Chlorophyceae): Applications to aquaculture systems. - Aquaculture 15, 373-376.

Hasset, R. P. \& Landry, M. R., 1982. Digestive carbohydrase activities in individual marine copepods. - Mar. Biol. Lett. 3, 211-221.

Hirche, H. L., 1981. Digestive enzymes of copepodids and adults of Calanus finmarchicus and $C$. helgolandicus in relation to particulate matter. - Kieler Meeresforsch., Sonderh. 5, 174-185.

Itami, K. \& Yoshinori, H., 1977. Studies on the cultivation of the marine copepods. III. On the cultivation of Tigriopus japonicus in the water tanks with honey-comb. - Bull. Hyogo pref. Fish. Exp. Stn 17, 53-68.

Kahan, D., 1979. Vegetables as food for marine harpacticoid copepods. - Aquaculture 16, 345-350.

Kahan, D., 1981. Effects of some ecological factors on the growth of the copepod Schizopera elatensis - potential food organism for hatcheries. - Kieler Meeresforsch., Sonderh. 5, 544-553.

Kahan, D., Uhlig, G., Schwenzer, D. \& Horowitz, L., 1982. A simple method for cultivating harpacticoid copepods and offering them to fish larvae. - Aquaculture 26, 303-310.

Kuhlmann, D., Quantz, G. \& Witt, V., 1981. Rearing of turbo larvae (Scophthalmus maximus L.) on cultured food organisms and postmetamorphosis growth on natural and artificial food. Aquaculture 23, 183-196.

Miliou, H. \& Moraittou-Apostolopoulou, M., 1991. Combined effects of temperature and salinity on population dynamics of Tisbe holothuriae Humes (Copepoda: Harpacticoida). - Arch. Hydrobiol. $121,431-448$.

Nash, C. E., 1977. The breeding and cultivation of marine fish species for mariculture. - Actes de colloques, CNEXO 4, 1-10.

Nash, C. E. \& Kuo, C. M., 1975. Hypotheses for problems impeding the mass propagation of grey mullet and other finfish - Aquaculture 5, 119-133.

Nassogne, A., 1970. Influence of food organisms on the development and culture of pelagic copepods. - Helgoländer wiss. Meeresunters. 20, 333-345.

Provasoli, L, Shirashi, K. \& Lance, J. R, 1959. Nutritional idiosyncrasies of Artemia salina and Tigriopus in monoxenic culture - Ann. N. Y. Acad, Sci. 77, 250-261. 
Raymont, J. E. G., Morris, R. J., Ferguson, C. F. \& Raymont, J. K. B., 1975. Variations in the aminoacid composition of the lipid-free residues of marine animals from the Northeast Atlantic. - J. exp. mar. Biol. Ecol. 17, 261-267.

Rieper, M., 1978. Bacteria as food for marine harpacticoid copepods. - Mar. Biol. 45, 337-345.

Rieper, M. \& Flotow, C., 1981. Feeding experiments with bacteria, ciliates and harpacticoid copepods. - Kieler Meeresforsch., Sonderh. 5, 370-375.

Rothbard, S., 1976. Experiments in mass culture of the marine copepod Tigriopus japonicus (Mori) on a bed of crushed sea weed Ulva petrusa (Kjelman). - Bamidgeh 4, 80-105.

Sargent, J. R. \& Falk-Petersen, S., 1981. Ecological investigations on the zooplankton community in Balsfjorden, northern Norway: lipids and fatty acids in Meganyctiphanes norvegica, Thysanoessa raschi and $T$. inermis during mid-winter. - Mar. Biol. 62, 131-137.

Takano, H., 1971. Breeding experiments of a marine littoral copepod Tigriopus japonicus Mori. Bull. Tokai reg. Fish. Res. Lab. 64, 71-80.

Tanaka, Y., Marsuguchi, H., Katayama, T., Simpson, K. L. \& Chichester, C. O., 1976. The biosynthesis of astaxanthin. XVII. The metabolism of the carotenoids in the prawn Penaus japonicus Bate, - Comp. Biochem. Physiol. 31, 959-967.

Uhlig, G., 1980. Microfaunal food organisms for mariculture. - Spec. Publ. European Maricult. Soc. 6, 93-115.

UNEP/FAO/IAEA, 1987. Test of acute lethal toxicity of pollutants to marine físh and invertebrates. Ref. Meth. mar. Pollut. Stud. 43, 1-24.

Wakil, S. J., Stoops, J. K. \& Joshi, V. C., 1983. Fatty acid synthesis and its regulation. - A. Rev. Biochem. 152, 537-579.

Zar, J. H., 1984. Biostatistical analysis (second edition). Prentice-Hall, Englewood Cliffs, N. J., $718 \mathrm{pp}$. 